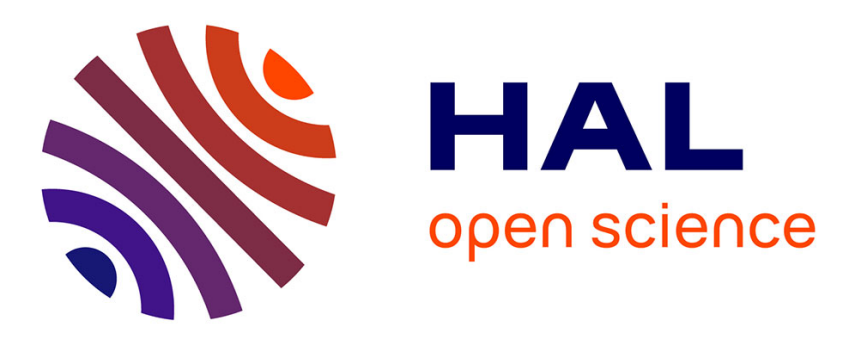

\title{
Towards modelling of decay risk of wooden materials
} H. Viitanen, T. Toratti, L. Makkonen, R. Peuhkuri, T. Ojanen, L. Ruokolainen, J. Räisänen

\section{To cite this version:}

H. Viitanen, T. Toratti, L. Makkonen, R. Peuhkuri, T. Ojanen, et al.. Towards modelling of decay risk of wooden materials. European Journal of Wood and Wood Products, 2010, 68 (3), pp.303-313. 10.1007/s00107-010-0450-x . hal-00599240

\section{HAL Id: hal-00599240 \\ https://hal.science/hal-00599240}

Submitted on 9 Jun 2011

HAL is a multi-disciplinary open access archive for the deposit and dissemination of scientific research documents, whether they are published or not. The documents may come from teaching and research institutions in France or abroad, or from public or private research centers.
L'archive ouverte pluridisciplinaire HAL, est destinée au dépôt et à la diffusion de documents scientifiques de niveau recherche, publiés ou non, émanant des établissements d'enseignement et de recherche français ou étrangers, des laboratoires publics ou privés. 


\title{
Towards modelling of decay risk of wooden materials
}

H. Viitanen, T. Toratti, L. Makkonen, R. Peuhkuri, T. Ojanen, VTT Technical Research Centre of Finland, Box 1000, 02044 VTT, Espoo, Finland

L. Ruokolainen, J. Räisänen

Department of Physics, University of Helsinki, Box 64, 00014, Helsinki, Finland

This article is dedicated to Gerd Wegener on the occasion of his retirement as professor at the Technische Universität München.

Corresponding author: L. Makkonen, VTT Technical Research Centre of Finland, Box 1000, 02044 VTT, Finland. e-mail: lasse.makkonen@vtt.fi,

\begin{abstract}
An empirical model for wood decay development which can be incorporated into a hygrothermal model of building physics is presented. The model is applied to the ERA-40 reanalysis data, based on six-hour weather observations in Europe, to estimate wood decay in different parts of Europe. These studies provide new tools for evaluating the durability and service life of wooden products and a preliminary European wood decay risk level map. The effects of the projected climate change on wood decay may also be considered by this methodology.
\end{abstract}

\section{Zur Modellierung des Fäulerisikos von Holzprodukten}

\section{Zusammenfassung}

Vorgestellt wird ein empirisches Modell zur Holzfäuleentwicklung, welches sich in ein bauphysikalisches hygrothermisches Modell einbauen lässt. Zur Bestimmung der 
Holzfäule in verschiedenen Teilen Europas benutzt das Modell die aufbereiteten ERA-40 Daten, die auf sechsstündigen Wetterbeobachtungen in Europa basieren. Diese Untersuchungen liefern neue Möglichkeiten zur Bestimmung der Dauerhaftigkeit und der Nutzungsdauer von Holzprodukten sowie eine vorläufige Darstellung des Holzfäulerisikos in Europa. Die Einflüsse der erwarteten Klimaänderung auf die Holzfäule können mit diesem Verfahren ebenfalls untersucht werden.

\section{Introduction}

The long term durability of structures depends on the effect of persistent moisture that, in combination with favourable temperature conditions and exposure time, may deteriorate materials. The time of wet conditions is a useful indicator for development of mould growth on a surface. Persistent high humidity exposure and high moisture content of wood is a high risk for bio deterioration of unprotected timber, first for mould and finally for decay fungi. Decay reduces the strength of timber and is the main factor to be considered in assessing the durability of wooden structures (Foliente et al. 2002).

For most decay fungi, optimum wood moisture condition is around 25 to $30 \%$ (Carll and Highley 1999, Viitanen 1996). This means e.g. that for decay to develop in pine sapwood, the ambient relative humidity of air (microclimate humidity conditions), RH, should stay above 95 - 99\% for weeks or months, depending on the temperature (Viitanen 1996). For wood products and other species of wood, the critical factors may be different from those of untreated pine sapwood: For example, the resistance of pine heartwood against decay is higher than that of sapwood, and coatings protect wood against water and high humidity as well as micro-organisms. On the other hand, claddings, roofs and lower parts of walls can be exposed to frequent water immersions in addition to a high humidity, which will add to the moisture content of wood and cause an attack by fungi and micro-organisms.

A method to evaluate the exposure to wood decay is to measure or model the moisture or humidity level of the material environment (microclimate) over a long period. Water activity is the most important factor for the development of organisms in a porous organic material such as wood (Boddy 1983, Viitanen 1996). The time of wetness in the exterior climate, however, does not necessarily correspond to the time 
of wetness in different parts of the construction or the material. The microclimatic conditions close to the material are the main acting forces for biological deterioration in surface of materials, but the moisture conditions inside the wood material also depend on the water absorption and moisture capacity of the material. Microclimate is a result of several simultaneous factors: macroclimate (rainfall, temperature, humidity, air pressure conditions etc.) and mesoclimate (location of the building, structural details and the materials used). The time of wetness may be high in the building structure even in a cold and dry climate if the moisture performance of the structure is poor. In any case, a low temperature will diminish the risk of growth of fungi and decay development.

Comprehensive research has been done previously on mould and decay growth as well as empirical modelling on timber (Viitanen 1996; Sedlbauer 2001; Viitanen et al. 2003; Leicester et al 2003; Wang et al 2008). This paper applies an empirical decay activity model of wood to evaluate the decay process in different climatic exposure conditions. The model is used to provide a climatic overview of the decay risk of wood in exterior conditions above ground in Europe.

\section{Durability of wooden structures}

\subsection{Definition of service life}

Service life is defined as the period of time after installation during which a building or its parts meet or exceed the performance requirements (ISO 2007). Performance requirement means the minimum acceptable level of a critical property, which can be defined as a limit state. This defines the limit between acceptable performance and non-acceptable performance. An example of limit state is the onset of mould growth in wood in the building envelope, which can be regarded as non-acceptable since it may create health problems in a building. This is comparable to a serviceability limit state for structures. Another example is an attack by decay fungi, which will reduce the capacity of a load bearing structure. In this case, the limit state can be formulated in the same way as for mechanically loaded structures considering that the capacity of the structure is reduced with time. The effect of decay may be considered as mass loss of wood caused by the decay fungi, since the mass loss strongly correlates with the loss in strength (Wilcox 1978). 


\subsection{Parameters affecting durability}

The type of data which are needed for durability and service life evaluation depends on the type of degradation mechanism considered. Since moisture and temperature are generally very important factors, one will need climate data and exposure conditions close to the surface of the building component. These data are usually called the "microclimate", and they depend on many factors. The starting point must be the meteorological data defining the "regional climate" in the area where the building is situated: temperature, relative humidity, solar radiation, rain and wind intensity and duration. The next step is to define the "mesoclimate", i.e. the climate conditions close to the building, but still undisturbed by the properties of the wood material and the shape of the structure. Assessing the microclimate is the last step towards modelling the actual moisture and temperature conditions within the material and the resulting decay process.

In practice, ambient moisture condition is the most important factor affecting the durability of wood, and the classification of usage conditions is usually based on the evaluation of the water exposure during the lifetime. The outer part of buildings, claddings, fences, balconies, terraces are exposed to high humidity and water, but discolouring of uncoated wood in this structure is often considered to be a normal ageing process. In water damage cases, these components are exposed to a very high humidity and may be attacked by mould and decay fungi or insects. This, however, is not an intended use condition.

Since different wood materials, coatings, design of the building and its details, local climate conditions and the environment all affect durability, the mesoclimatic exposure conditions should be evaluated using building physics calculations. Implementation of a decay model to such calculations gives an estimate of the exposure conditions for durability evaluation.

There are several hygrothermal performance criteria for structures. Suitable criteria depend on materials and deterioration aspect, e.g. structural strength and durability, service life time, aesthetics, effect on indoor air, etc. One of the first biological signs of ageing is mould growth that does not directly affect durability. Decay of wooden structures is possible under severe humidity conditions when the materials are wet for long periods. This case is typical only in exterior structure parts that are affected by rain or when there is some failure in structure coatings or sanitary piping or 
equipments. This work concentrates on modelling the decay process of wood emphasizing service life from the point of view of structural rigidity.

\subsection{Role of coating in wood durability}

The task of coatings is to protect wood against water, weathering and high humidity as well as against micro-organisms like bacteria and fungi.

One of the most important functions of a coating for exterior use is the protection against liquid water and water vapour. The degree of reduction of moisture sorption depends on the coating type. The influence of the wood species for liquid water absorption is considerable for low build coatings whereas for high build coatings with sufficient film thickness the wood species is of minor importance.

The drying of coated wood depends on the coating type and condition of the coating. Permeability of the water-based coatings is higher than that of oil or alkyd coatings. Alkyds are effective in preventing moisture penetration, but they are liable to trap water which may have entered through unsealed end-grain or defects in the coating film. Desorption of the coated wood may be lower than absorption, thus leading to an increased moisture content. Coatings having high permeability provide the opportunity for moisture to escape. Under these circumstances the moisture gradient may become high and water can penetrate deeper into the wood, and the wood will dry slower. The moisture properties of coated wood may change during ageing. In addition, the colour of the pigment will have influence on the moisture contents. Dark colour absorbs more energy, and the wood will dry faster than wood coated with coating having lighter pigment.

In addition to wood moisture content, the resistance to crack formation also is an important factor influencing the durability of wood. Deep cracks collect water from rainfall and may develop favourable moisture content for mould, blue stain and decay fungi.

When using the decay risk modelling for evaluation of the effect of exposure conditions, the evaluation should be focused on the water activity of wood below the coating. In this stage, the models are not yet so advanced that this type of modelling could be performed for coated products. If water activity, temperature and time periods of these conditions inside the wood can be evaluated, the decay risk inside the wood could also be evaluated. When the moisture content of pine sapwood is 
above $30 \%$ (when water activity is around 1) for a long period and temperature is suitable for organisms to develop, the risk of decay exists.

\subsection{Decay development}

There is significant variation within the growth condition of different fungus species (Heilmann-Clausen and Boddy 2005). Decay can be caused by brown rot, white rot and soft rot fungi. Consequently, one needs an overall evaluation of the growth activity and decay development of a typical example fungi (mixture of mould/bluestain fungi) or typical decay fungi (e.g. Coniophora puteana or Gloeophyllum sepiarium). Such knowledge of the development of mould and decay already exists (Viitanen 1996). Using the updated empirical decay development model and measured climatic exposure the authors will here provide information on the most/least hazardous areas for wood decay in Europe. The model is based on laboratory experiments on pine sapwood. In the future, modifications of this model for other materials should be done by studying the decay resistance of other wood species and materials and experimentally finding the corresponding relationships. For mould development, the ambient critical relative humidity level of the microclimate is between RH 80 and $95 \%$ as shown in Fig. 1.

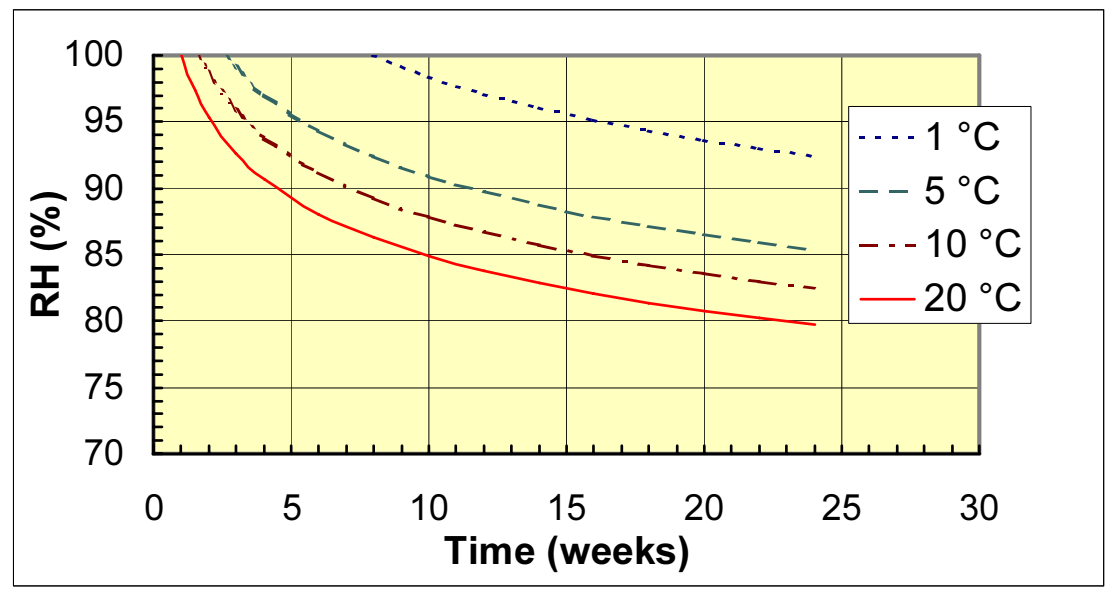

Fig. 1 Relative humidity of the ambient air (RH) and temperature isopleths as a function of time for start of mould growth in untreated pine sapwood (Viitanen 1997a).

For decay development and serious problems to be achieved in the untreated pine sapwood, the relative humidity of ambient air (microclimate conditions) should be above RH 95 - 99\% for weeks or months, as shown in Figure 2. 
For other wood products, as well as for coated or treated or modified wood, the critical values may be different. Furthermore, UV light deteriorates the outer surface of wood, especially when liquid water is available - this effect is not included in the experimental data of this study.

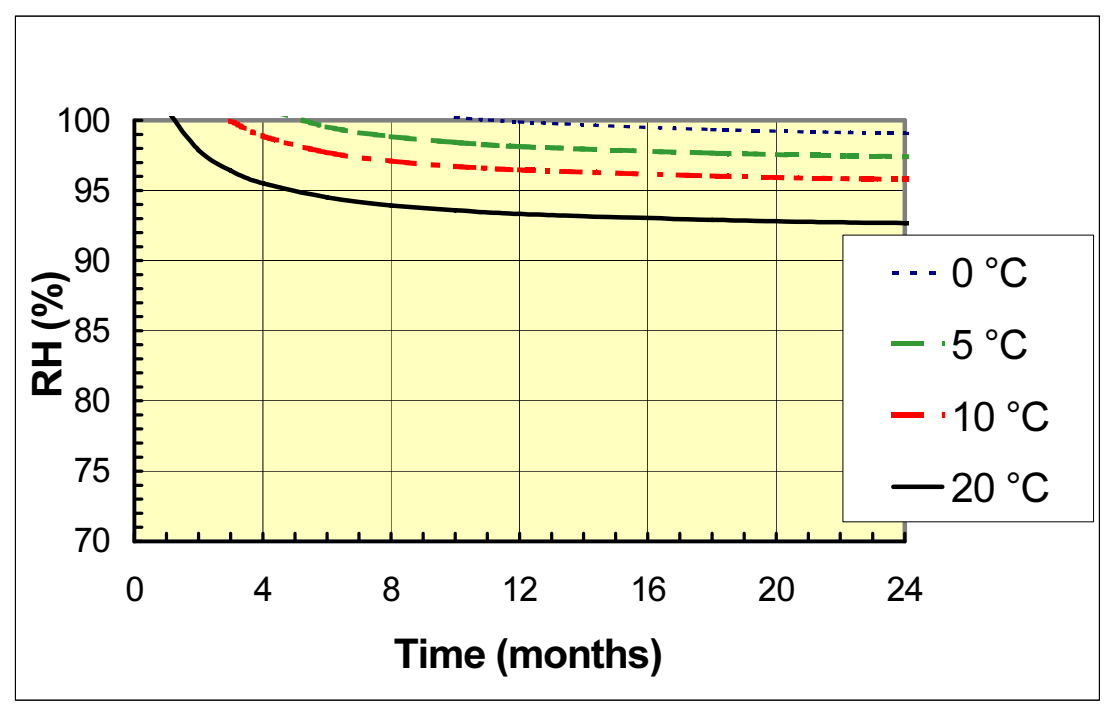

Fig. 2 Relative humidity of the ambient air (RH) and temperature isopleths as a function of time for start of decay development (mass loss less than 3\%) in untreated pine sapwood (Viitanen 1997b).

Greyish colour of wood surface and aging of coated wood is caused by the combined action of water, UV light and micro-organisms (mould and blue-stain fungi). The isopleths shown above can be used for evaluation of dose - response relation between mould / decay and humidity, temperature and exposure time. For mould and decay to develop, different dose response relations exist. Figure 3 shows an empirical model of development of decay in pine sapwood as mass loss of wood in accelerated test under "worst case scenario" of high humidity conditions at different temperatures. 


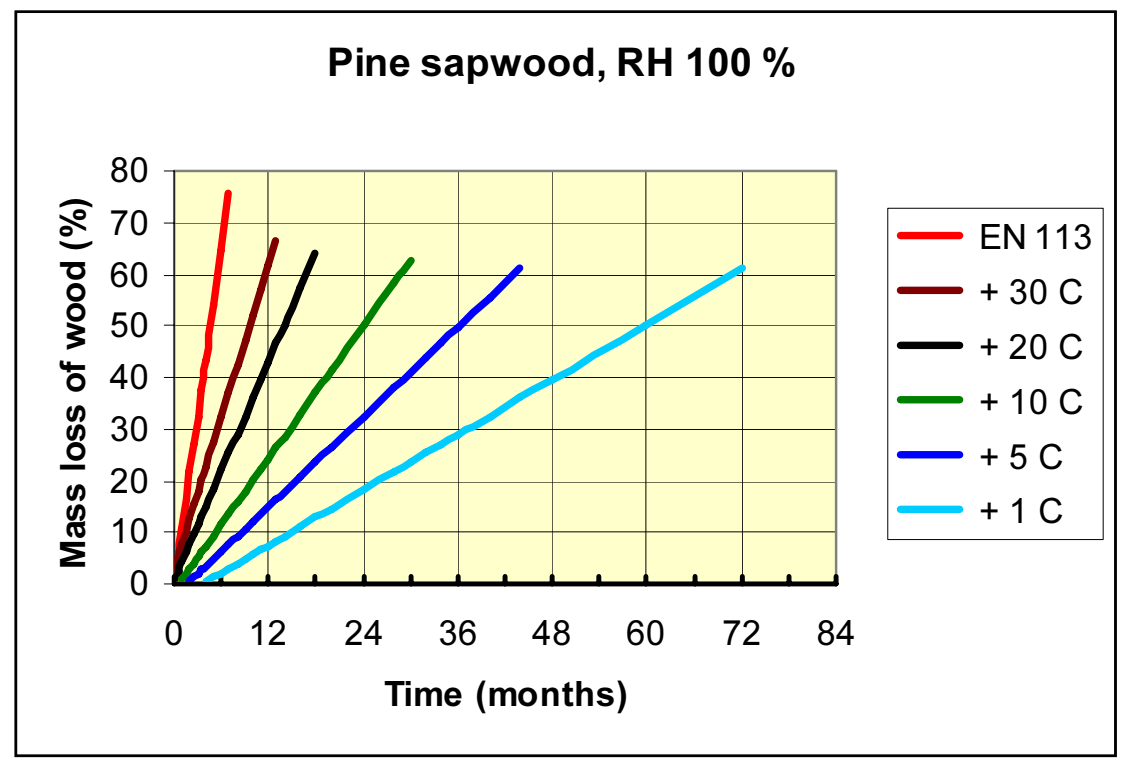

Fig. 3 Development of decay of Coniophora puteana in accelerated decay test (EN 113:1997) and at high humidity (RH 100\%) of ambient air at different temperatures. Development of decay is evaluated using mass loss value caused by the fungus in untreated pine sapwood. The curves are fits to the mean values of laboratory test data (Viitanen 1996).

\section{Model development}

\subsection{From experimental data to modelling}

In the experimental work for modelling the development of mould and decay by Viitanen and Ritschkoff (1991 a, b) and Viitanen (1996) the progress of decay was evaluated using mass loss of wood. Mould growth was evaluated using a mould index. Mould growth and decay development are separated processes, and the models developed are also different.

The growth conditions and decay development of a typical brown rot fungus Coniophora puteana (Schum. ex Fr.) P. Karsten (BAM Ebw. 15) was studied in Scots pine (Pinus sylvestris L.) and Norway spruce (Picea abies Karst.) by exposures at $0,5,15,20$ and $30{ }^{\circ} \mathrm{C}$ using $\mathrm{RH}$ of $86-88,90-92 \%, 96-98 \%$ and $99-100 \%$ under laboratory conditions (Viitanen 1997b). A regression model was presented for the critical response time periods of temperature and humidity conditions allowing the initiation and development of decay as expressed by the mass loss of wood. The response time for decay development in wood was strongly dependent on the temperature: after three months of exposure at RH of 96 and $100 \%$ and at $30{ }^{\circ} \mathrm{C}$, the 
wood was heavily attacked and decayed by $C$. puteana but after one year of exposure in different humidity conditions no decay was detected at $0{ }^{\circ} \mathrm{C}$. According to the regression model the lowest humidity conditions for decay development lie above $\mathrm{RH}$ of $90-92 \%$ during 60 months of exposure time at $30^{\circ} \mathrm{C}$, but in the actual test no decay was found in this exposure condition. The critical humidity condition of ambient air for decay development was above RH $94-95 \%$. Between 0 and $5{ }^{\circ} \mathrm{C}$, the lowest humidity conditions for decay development lie around $\mathrm{RH}$ of $97 \%$ and the wood moisture content around the fibre saturation point.

\subsection{Development of an empirical model of decay development}

In the references above, the following regression equation (Eq. 1) was developed for the decay growth of brown rot in pine sapwood under constant conditions:

$$
\begin{aligned}
& M L(R H, T, t)=-42.9 t-2.3 T-0.035 R H \\
& +0.14 T \cdot t+0.024 T \cdot R H+0.45 R H \cdot t
\end{aligned}
$$

where ML is the mass loss in percentage of the original mass, $t$ is time in months, $\mathrm{T}$ is air temperature in ${ }^{\circ} \mathrm{C}$, and $\mathrm{RH}$ is the relative humidity in air in $\%$.

This growth model, expressed as mass loss, only applies when $\mathrm{T} \geq 0{ }^{\circ} \mathrm{C}$ and when RH $\geq 95 \%$ (Viitanen and Ritschkoff 1991). The model produces growth rates, as shown in Fig. 4, where the growth is plotted at a constant temperature of $15^{\circ} \mathrm{C}$.

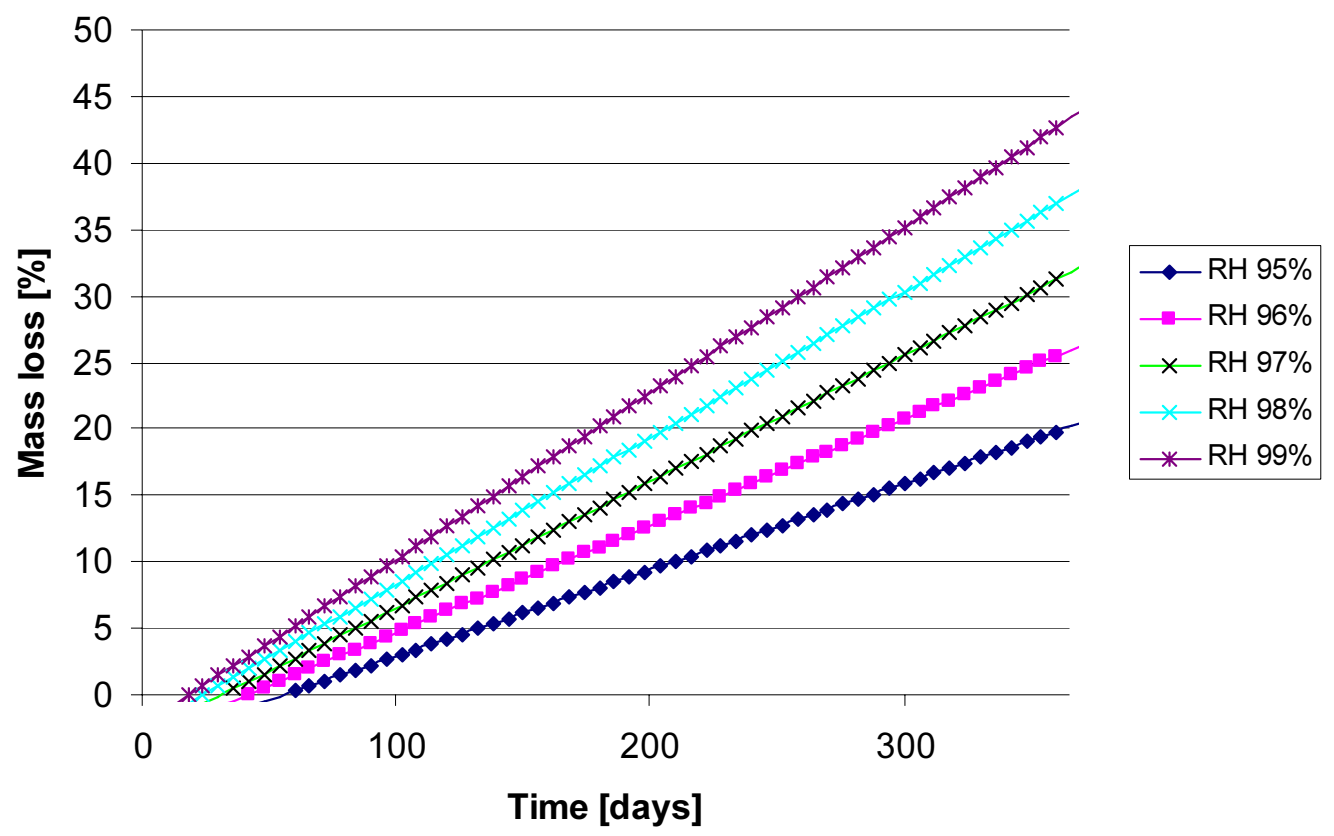

Fig. 4 Growth of decay as expressed by mass loss at a constant temperature of $15{ }^{\circ} \mathrm{C}$ for small untreated pine sapwood samples at different ambient air humidity conditions. 
Figure 4 shows that the mass loss does not occur immediately when the wood is exposed to these high humidity environments: The curves do not pass the $\mathrm{x}$-axis through the origin. Thus, there is a time lag, or as named here, a critical time in the beginning of the process. Using the empirical model in Eq. (1), the activation time may be calculated and is shown in Fig. 5.

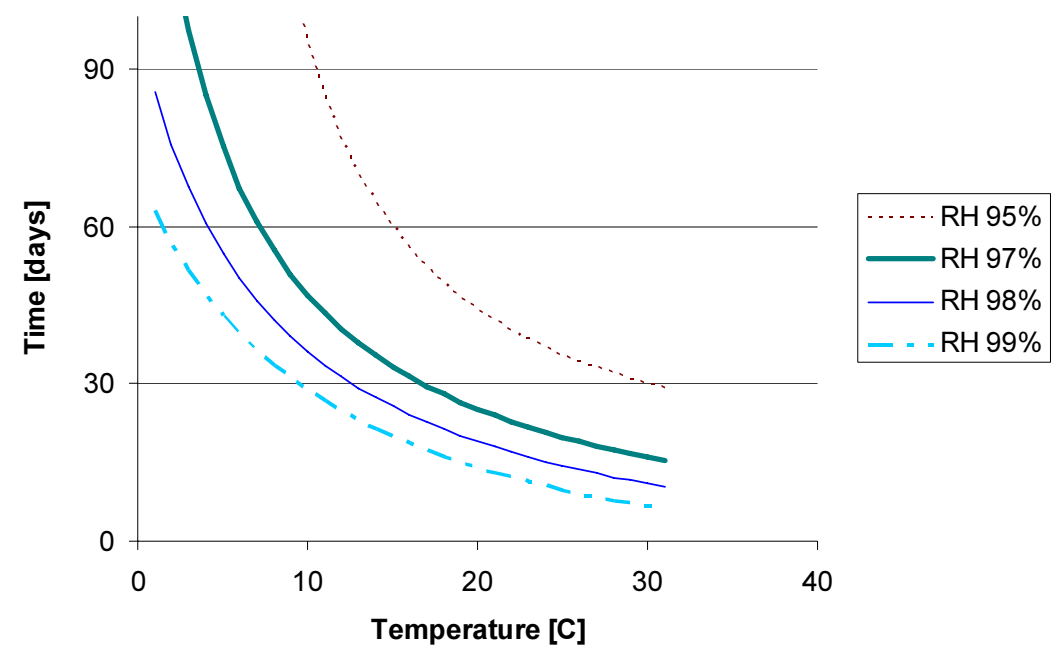

Fig. 5 Calculated critical time before decay (mass loss process) initiates at different constant temperatures (x-axis) and relative humidity levels of ambient air (different curves).

\subsection{Development of a model for variable temperature and relative humidity conditions}

In nature, the humidity and temperature conditions vary, so that laboratory experiments at constant conditions are not very useful as such. Based on the experimental findings presented above, a model for variable conditions is proposed here. This model is a time-stepping scheme and the development of decay is modelled as two processes:

\section{a) Activation process:}

A parameter $\alpha$ is defined as a relative measure of the state of the fungi with respect to its state at the initiation of the mass loss process. This parameter $\alpha$ is initially 0 and gradually grows to a limit value of 1 at which the mass loss is initiated.

The development of the parameter $\alpha$ with time is modelled, so that $\alpha$ is also able to decrease in dry conditions at a given rate. The time, in which $\alpha$ returns linearly from 1 to 0 , is assumed to be two years (17520 hours). This rate of decrease of $\alpha$ is an 
estimate based on scattered information and is not directly derivable from the experimental data of this study. This parameter in the model can easily be changed in the future when supporting data are available.

The model equations for the activation process are as given in Eq. (2). The critical time in Eq. (2) is obtained by solving Eq. (1) for mass loss $M L=0$. Here the critical time $t_{\text {crit }}$ is given in hours (not in months as $t$ in Eq. (1)).

$$
\begin{aligned}
& \alpha(t)=\int_{0}^{t} d \alpha=\sum_{0}^{t}(\Delta \alpha) \text {, where } \\
& \Delta \alpha=\frac{\Delta t}{t_{\text {crit }}(R H, T)} \text { when } T>0{ }^{\circ} C \text { and } R H>95 \% \\
& \Delta \alpha=-\frac{\Delta t}{17520} \text { otherwise } \\
& t_{\text {crit }}(R H, T)=\left[\frac{2.3 T+0.035 R H-0.024 T \times R H}{-42.9+0.14 T+0.45 R H}\right] \times 30 \times 24 \quad \text { [hours] }
\end{aligned}
$$

\section{b) Mass loss process:}

Mass loss occurs in the model when the fungi activation process has fully developed, i.e. $\alpha=1$, otherwise it does not occur. The mass loss is considered irrecoverable. The mass loss and activation processes only occur when the temperature is above 0 ${ }^{\circ} \mathrm{C}$ and the relative humidity is above $95 \%$. Outside these conditions the mass loss process is stopped in the model, and $\alpha$ will start to decrease

The mass loss process proceeds when $\alpha$ in Eq. (2) has reached 1. Then

$$
\begin{aligned}
& \text { Mass loss process when } \alpha \geq 1 \\
& M L\left(t^{\prime}\right)=\int_{\text {t at } \alpha=1}^{t^{\prime}} \frac{M L(R H, T)}{d t} d t=\sum_{\text {tat } \alpha=1}^{t^{\prime}}\left(\frac{M L(R H, T)}{d t} \times \Delta t\right) \\
& \frac{M L(R H, T)}{d t}=-5.96 \times 10^{-2}+1.96 \times 10^{-4} T+6.25 \times 10^{-4} R H[\% / \text { hour }]
\end{aligned}
$$

\subsection{Example calculations}

The model presented above is demonstrated here by examining an example on how the decay would develop in real outdoors conditions. The measured weather conditions in Helsinki - temperature and relative humidity - are given in Fig. 6. The 
climate data are hourly values for a one year period, and they are here used repeatedly for four years to obtain the modelling results in Fig. 7.

According to Fig. 7 there is no mass loss during the first two years since the condition of $\alpha=1$ is not reached. The decay in the following two years results in an overall mass loss of $1.15 \%$ in four years in this modelling example.

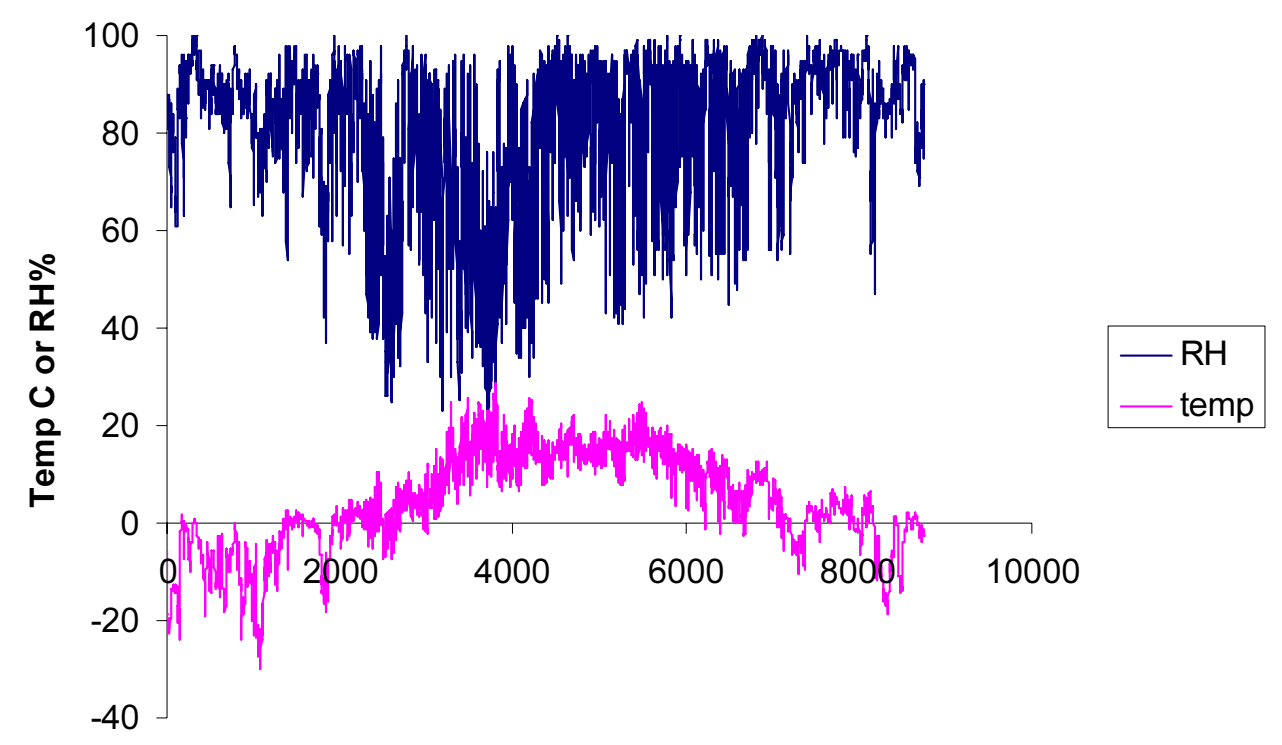

Time [h]

Fig. 6 Measured one-year climate in Helsinki used in the decay modelling example. 


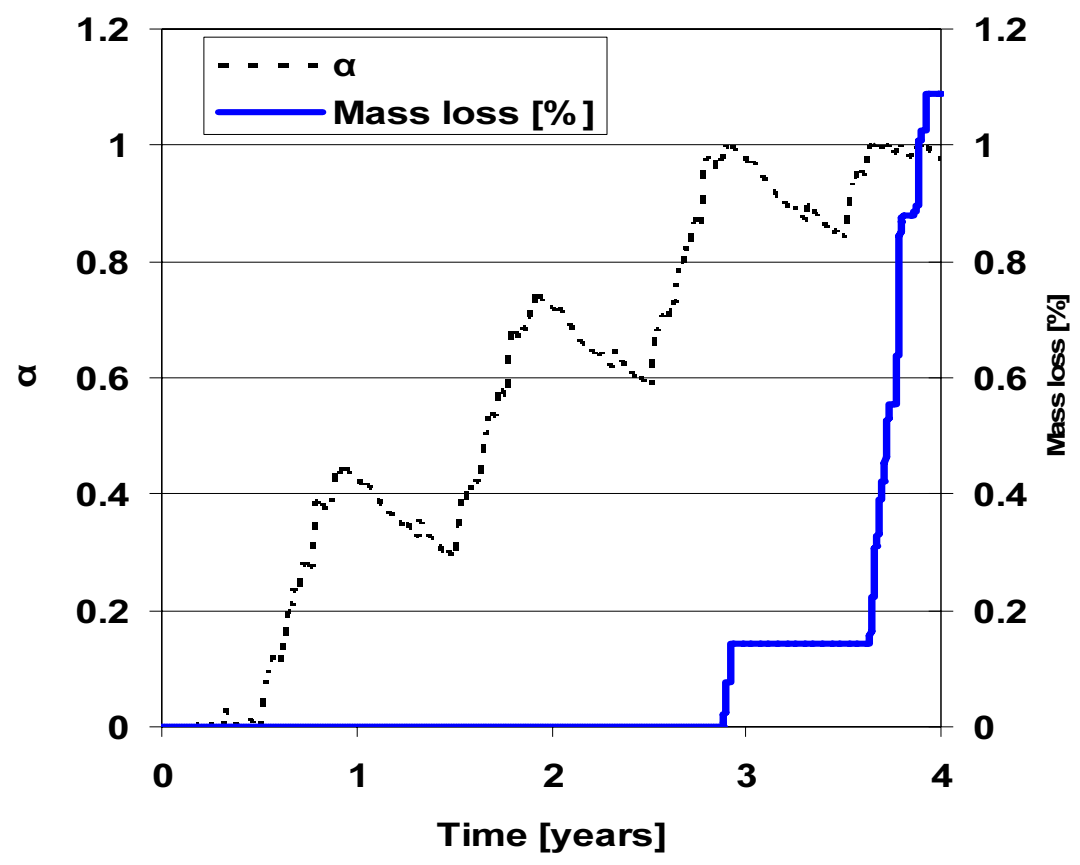

Fig. 7 Modelled activation and decay in four years based on repeated use of the meteorological data in Fig. 6.

\section{Simulation of decay development}

\subsection{Modelling of the wood decay risk by climate data}

The empirical wood decay model developed here (Chapter 3.3.) was run using the ERA-40 data for air temperature, humidity and precipitation at 6 hour intervals. ERA-40 is a massive data archive produced by the European Centre of MediumRange Weather Forecasts (ECMWF). The reanalysis involves a comprehensive use of a wide range of observational systems including, of course, the basic synoptic surface weather measurements at weather stations. The ERA-40 domain covers all of Europe and has a grid spacing of approximately $270 \mathrm{~km}$. The nature of the data and the reanalysis methods of ERA-40 are described in detail in Uppala et al. (2005). The resulting modelled mass loss in 1961 - 1970 at the calculation points of the ERA-40 grid were analyzed by a chart production software producing maps of wood decay in Europe (Figs. 8 and 9). In these calculations, the $\alpha$-factor of the empirical wood decay model was reduced during non-decay periods by the rate that corresponds to the recovery time of two years, as mentioned in Chapter 3.3. 
In the first simulation, the calculation was based on the relative humidity and temperature in air only. The results, presented in Fig. 8, therefore, represent the decay of uncoated wood that is outdoors but protected from getting wet by precipitation.

In the second simulation, the humidity of air was set to $100 \%$ during precipitation (at non-freezing temperatures). These results, presented in Fig. 9, thus model the decay of uncoated pine wood that is fully exposed to rainfall. Both results strictly speaking apply only for surfaces of small pieces of pine wood used in the experimental data, but the results can be considered to provide an indication of the eventual risk of wood decay more generally.
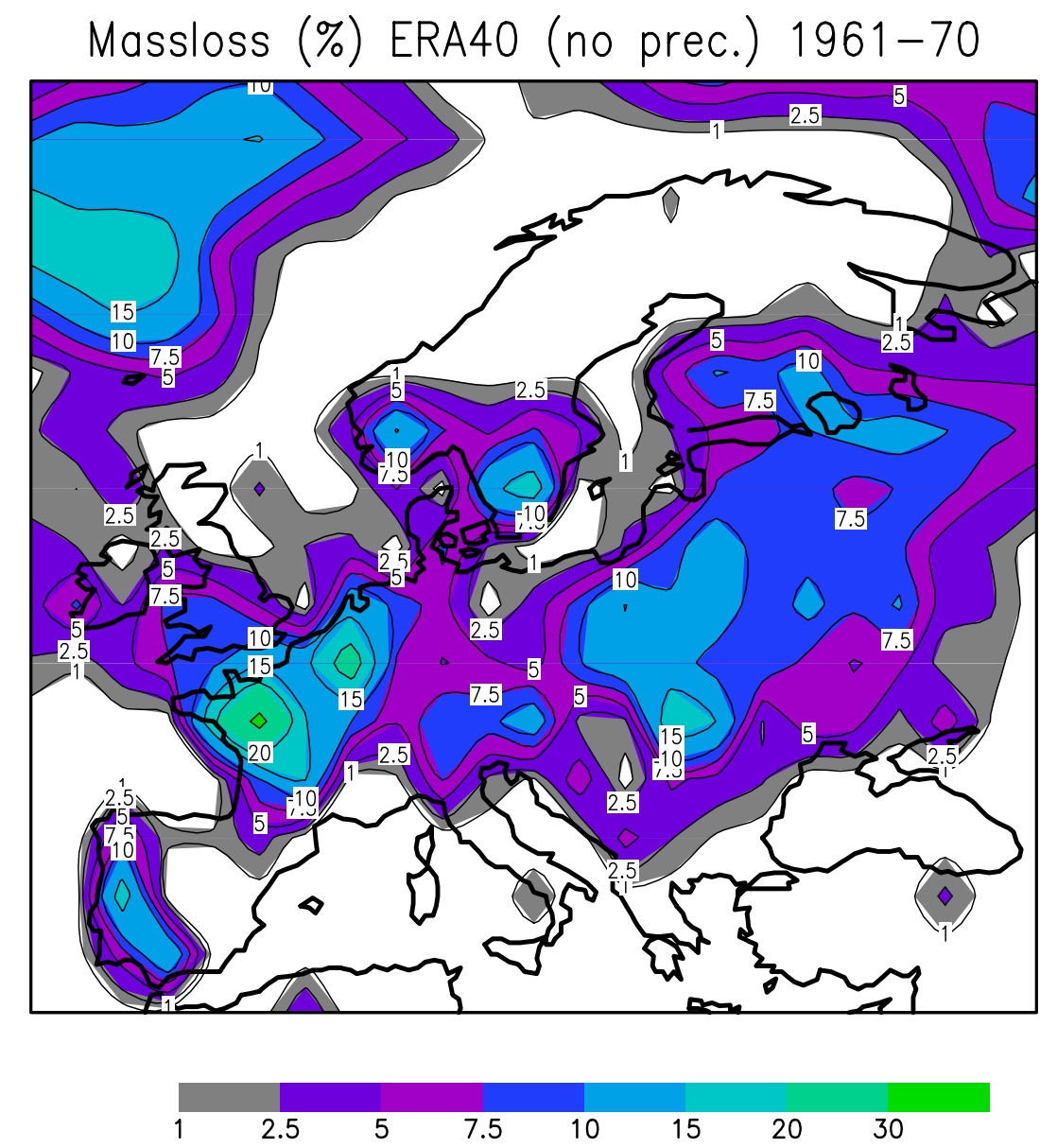

Fig. 8 Modelled evaluation of mass loss (in \%) of pine sapwood that is protected from rain in ten years in Europe. 


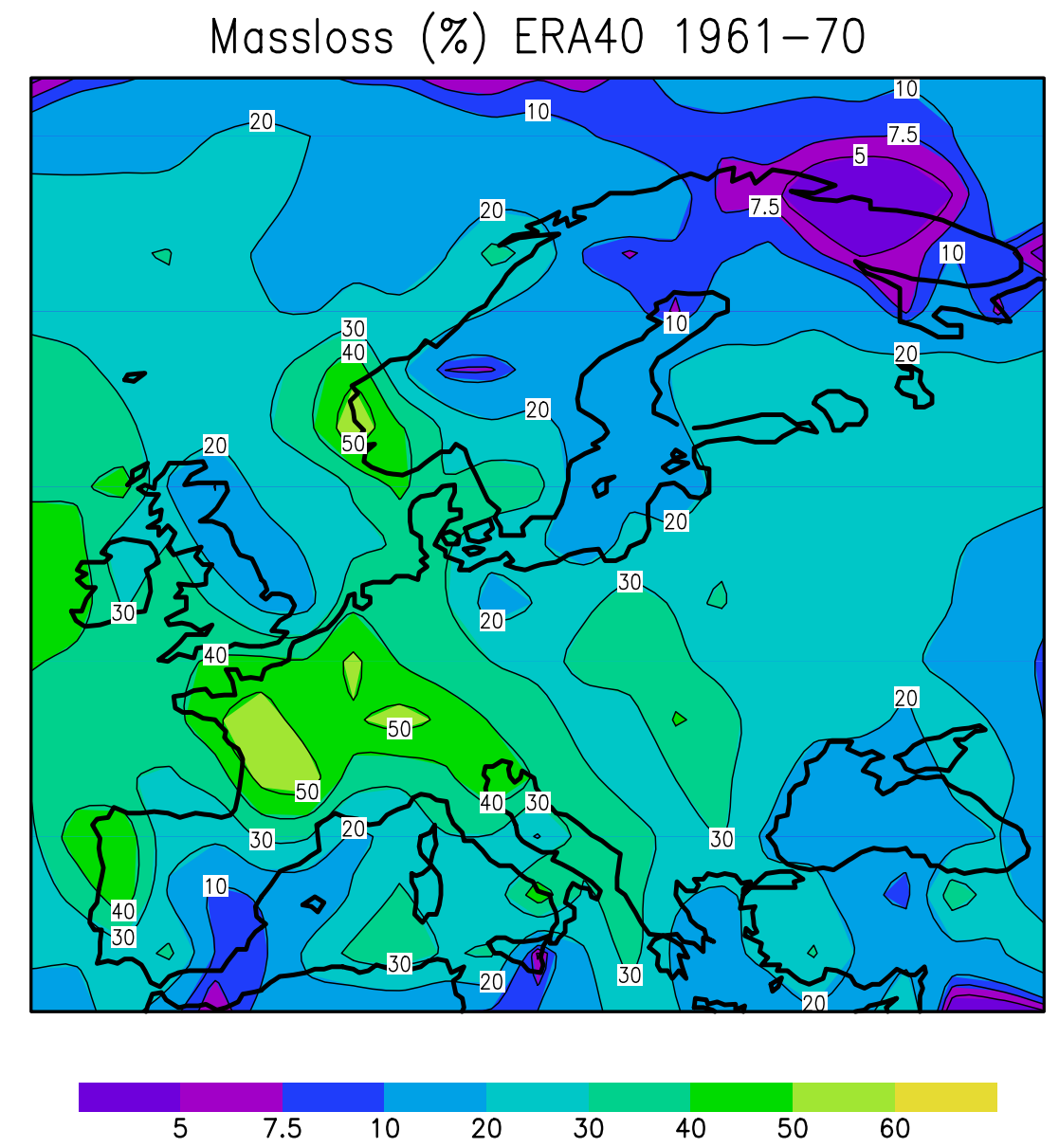

Fig. 9 Modelled evaluation of mass loss (in \%) of pine sapwood that is exposed to rain in ten years in Europe.

Rain exposure on external walls and other building components at a location is usually related to some typical wind directions because of driving rain. During rain at moderate or high wind the façades that are facing the wind are wet while the ones on the opposite side of the building remain dry. During long periods, this will result in a different exposure and risk of decay on wooden components.

In order to investigate this effect in Europe, further modelling was done so that, in the decay model the direction of the wind during rain was taken into account at all time steps. It was considered that a façade gets wet during rain when the wind speed exceeds $1 \mathrm{~m} / \mathrm{s}$. The wet facades at each time step were considered in this modelling as in the rain-exposed situation (Fig. 9) while the dry ones were modelled as in the rain-protected situation (Fig. 8). Thus, four additional maps for the wood decay in Europe were produced on the four vertical facades of a hypothetical rectangular building located so that one wall is aligned from East to West. These model results are presented in Fig. 10. 
The results show, that the highest exposure exists on western, southern and eastern walls, but will vary in different parts of Europe. On the northern walls, the exposure and decay risk seems to be the lowest.
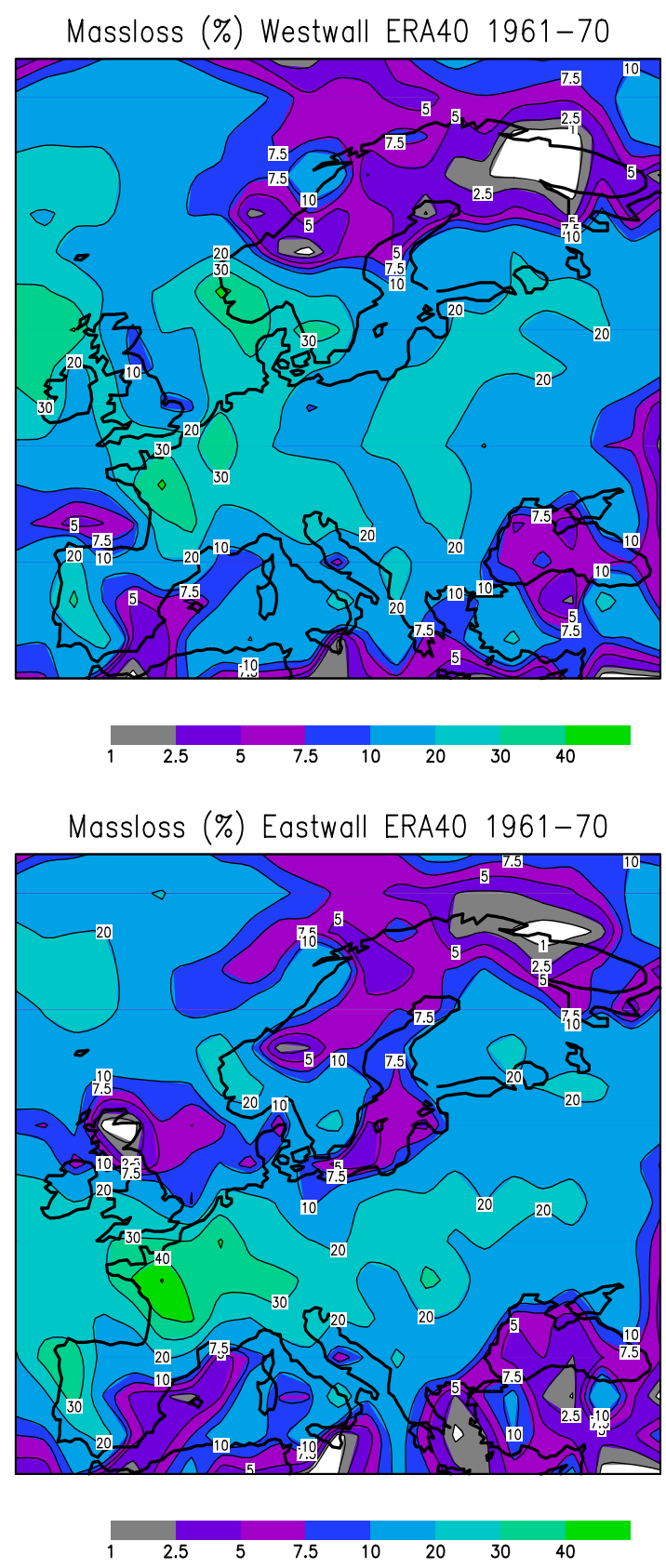
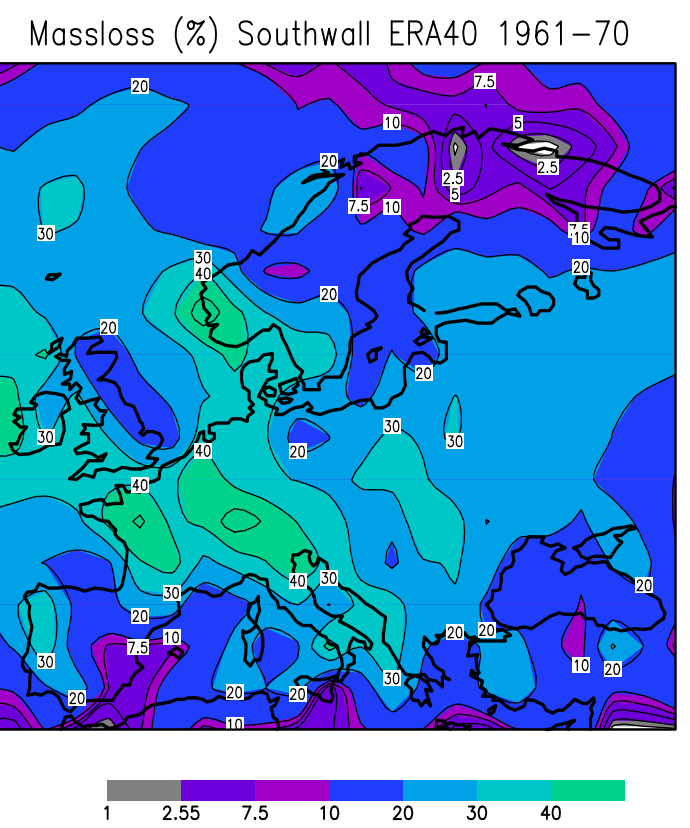

Massloss (\%) Northwall ERA40 1961-70
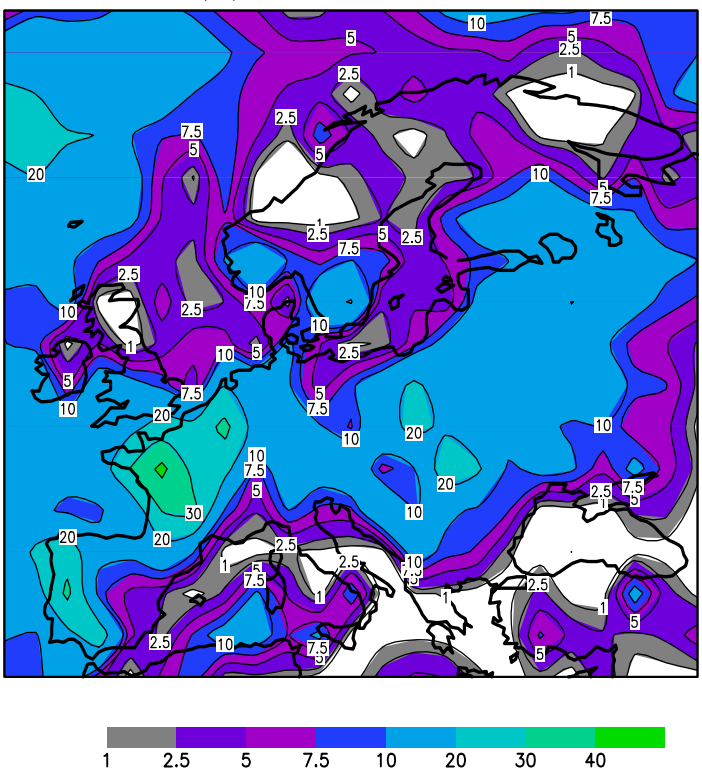

Fig. 10 Modelled evaluation of mass loss (in \%) of pine wood on differently aligned vertical surfaces exposed to driving rain in ten years in Europe. 


\subsection{Case study of a wooden structure}

An example of the practical use of the decay model in evaluation of the moisture safe design of constructions is given below.

The empirical model for decay developed here is suitable for post-processing the results of hygrothermal dynamic simulations. As an example, a well insulated cavity wall with untreated wooden exterior sheathing made from pine sapwood shown in Fig. 11 was used, and focus was put on the decay (mass loss) of the exterior surface. The geographical location and orientation, together with different assumptions for driving rain can be used as variables.

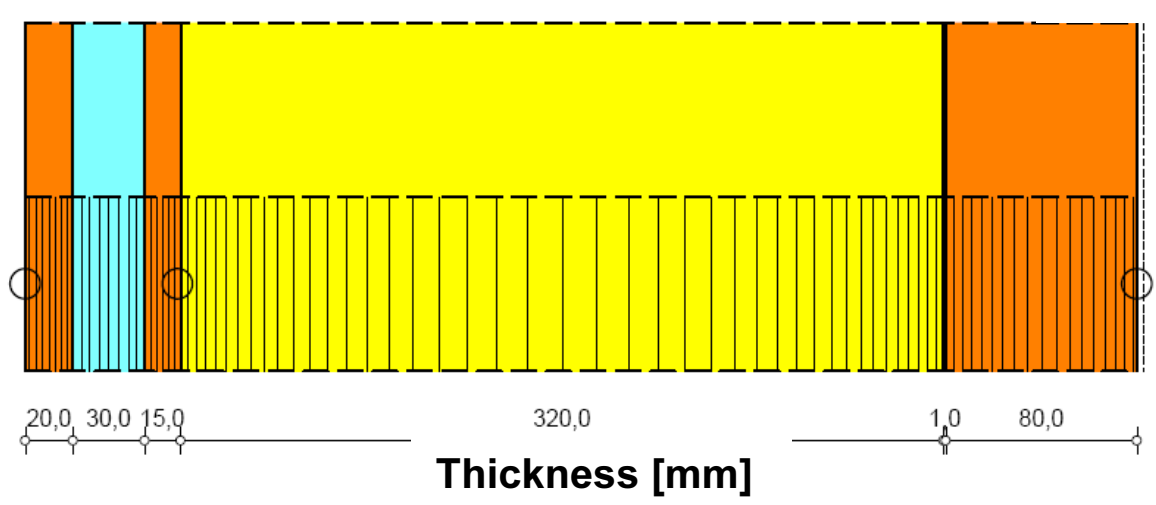

Fig. 11 Cross section of a well-insulated $(320 \mathrm{~mm})$ cavity wall with ventilated air cap $(30 \mathrm{~mm})$.

The simulations are performed with a hygrothermal simulation model Wufi 4.1, (Wufi 4.1 Pro software, Wärme und Feuchte instationär - Transient Heat and Moisture, The Fraunhofer Institute for Building Physics IBP) which solves the dynamic temperature and moisture conditions in a construction and can e.g. take into account the amount of water absorbed to a construction due to driving rain. The driving rain load $S_{d}$, is calculated as in Eq 4:

$$
S_{d}=s \cdot\left(R_{1}+R_{2} \cdot v\right)
$$

where $\mathrm{s}$ is precipitation intensity, $\mathrm{v}$ is the wind velocity in orthogonal direction to the surface and $R_{1}$ and $R_{2}$ are coefficients, e.g. $R_{1}=0$ for vertical facades and $R_{2}=0.2$ for undisturbed rain. 
The case is studied for a west oriented wall in three very different locations in Europe: Grenoble, Bergen and Sodankylä. The impact of the driving rain is studied by assuming either free driving rain $\left(\mathrm{R}_{2}=0.2\right)$ on a façade or reduced driving rain $\left(\mathrm{R}_{2}=0.07\right)$ on the centre of the facade due to the pressure field around a typical building.

Some examples on the output and the use of the developed model for decay in assessment of the building structures are given as follows. Figure 12 shows the impact of different climates on the decay development. According to the results, the mass loss seems to be much higher in a humid location like Bergen than in Central France. A cold location in Northern Finland gives no decay during three years.

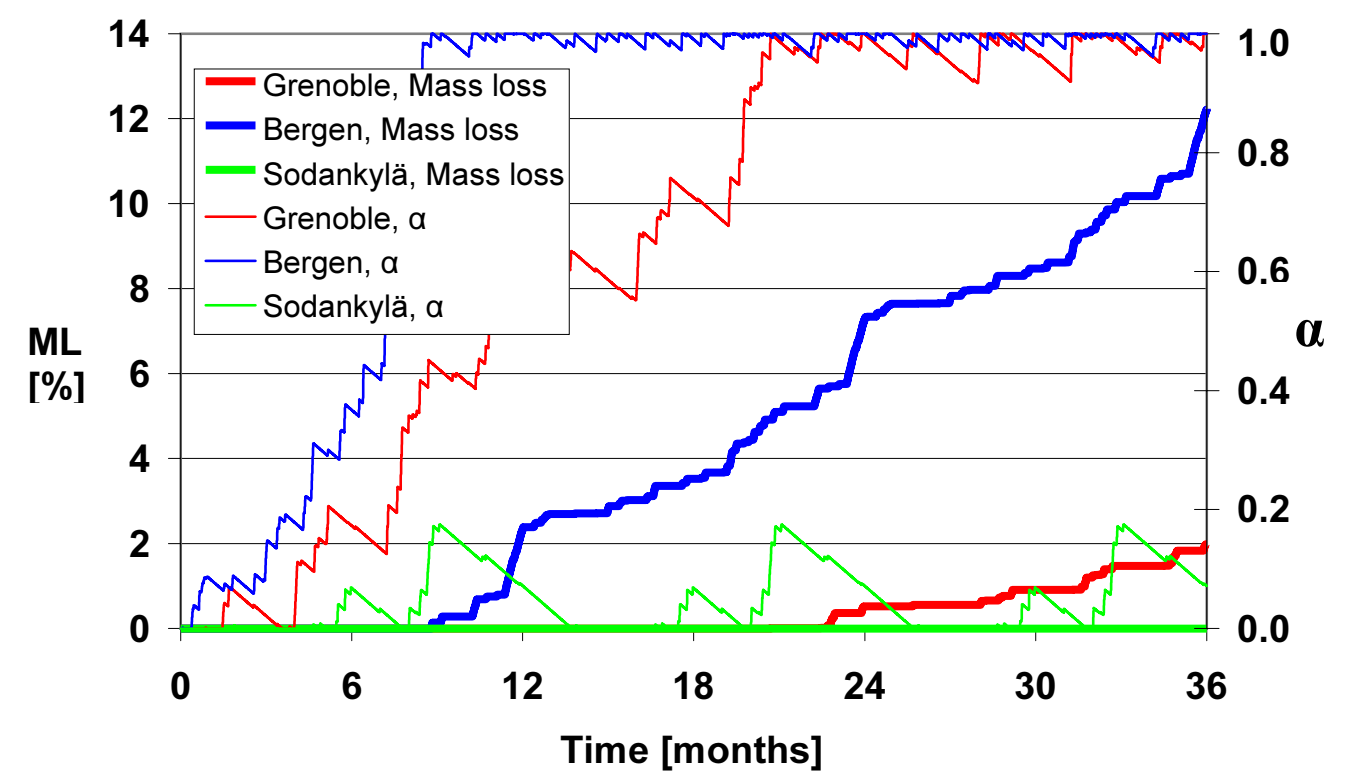

Fig. 12 Decay development during three years in untreated pine sapwood of a $20 \mathrm{~mm}$ thick exterior wooden sheathing at three locations in Europe as modelled using local weather data.

The influence of driving rain for these cases is shown in Figure 13. The results show that if the construction is properly protected against driving rain, decay can be avoided for a longer period. 


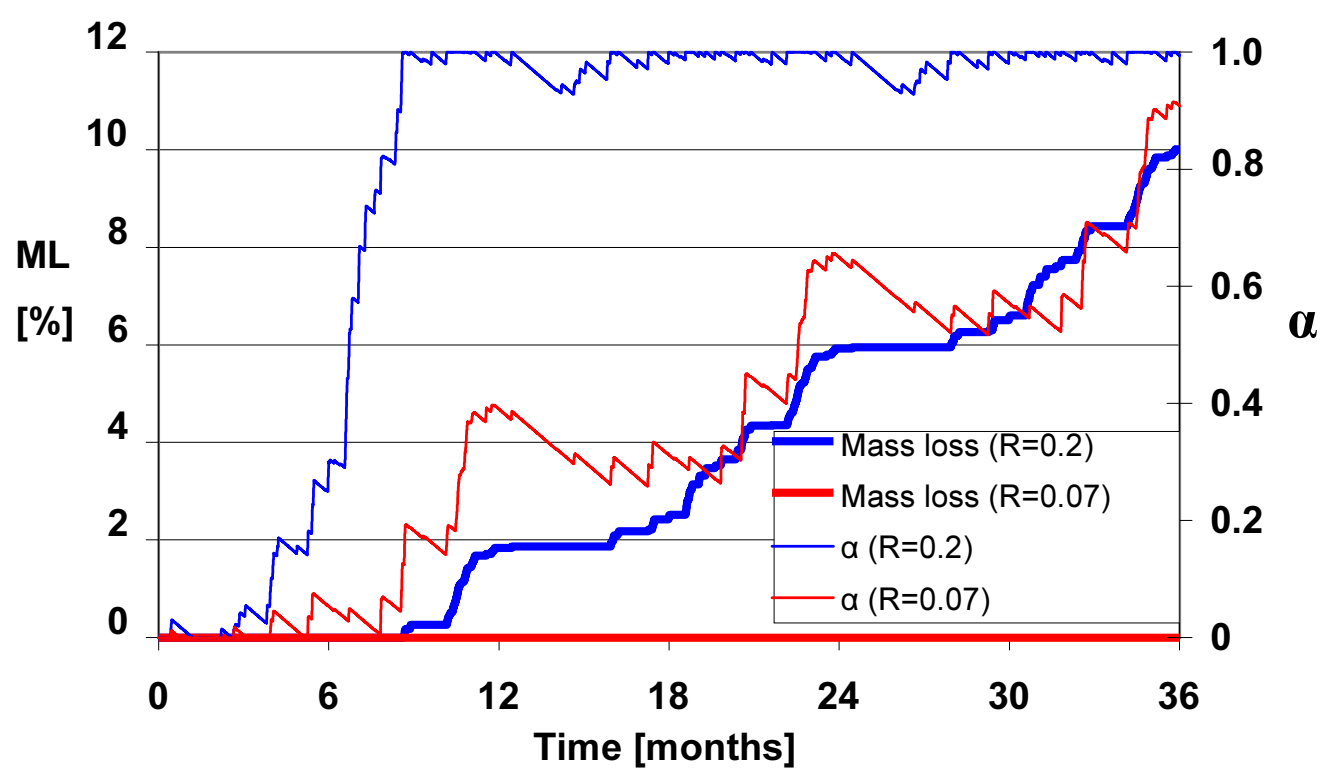

Fig. 13 Effect of the driving rain exposure coefficient $R$ on the decay development in untreated pine sapwood of a $20 \mathrm{~mm}$ exterior wooden sheathing. Weather data for the three years are from Helsinki.

\section{Discussion and Conclusion}

The evaluation of decay development in the model is based on the mass loss caused by the decay fungus on a sample with a given volume. The mass loss is an applicable variable for evaluating the decay development in wood since the correlation between mass loss and critical parameters of wood, e.g. modulus of rupture and strength, is high within the same wood species, especially within high mass loss values (Wilcox 1978; Brischke et al. 2006). The wood decay model thus provides a general picture of the effect of humidity, temperature and exposure time on the start and progress of the decay. However, the tests used for developing this model have been performed using small samples, and a sample volume correction factor is needed for practical applications of the model.

The basic model is an empirical regression equation for decay development in untreated pieces of pine sapwood under constant conditions (Viitanen 1996). Here it is demonstrated how a model of this kind can be used as a tool for building physics and service life evaluation. For detailed studies the limit state in terms of a mass loss level has to be defined. 
The resistance of wood species and coated wood products is often evaluated using accelerated tests simulating the "worst case scenario". When comparing the test results between treated and untreated pine sapwood, evaluation of the resistance of wood products under different actual conditions can be performed using the decay development model modified with this "resistance factor" (Brischke 2007). Brischke (2007) and Brischke and Rapp (2008) have developed dose response functions using wood moisture content, wood temperature and fungal decay which can be used to evaluate the implication of different exposure conditions. These functions may give lower decay rate and longer service life periods than those presented in the present paper. The model here is based on the experiments at constant conditions which may affect the evaluation results. Further development would require further measurements under cyclic conditions and better understanding of the moisture in wood under such conditions ( $\mathrm{Lu}$ and Leicester 1997).

The results of the wood decay simulations for Europe in Figures 8 to 10 lack verification, which can be obtained only by long-term experiments or observations of wood samples or structures using methods discussed by Råberg et al. (2005). Thus, the model results presented here are preliminary indicators only. Nevertheless, most geographical features of the model results seem logical. For example, wood decay is fast in warm and moist parts of Europe. Also, there is a clear difference between the modelled mass loss of wood that is protected from rain and wood that is exposed to rain, as one would expect. The results for differently aligned surfaces seem to reflect the typical prevailing winds in Europe during low pressure weather systems with rain.

A further development would be to combine the European maps of wood decay with the calculated decay based on hygrothermal simulations of wooden structures in different locations. Also, the connection of the modelled decay based on the ambient $\mathrm{T}$ and $\mathrm{RH}$ and the actual moisture content of wood should be studied further. Other aspects of modelling that require improvement include, for example, that it is difficult to simulate imperfect details of a structure, where the damage is most likely to happen.

The preliminary calculations in this work reveal a great effect of the time averaging of the climatic data on the resulting decay. It is concluded that the long averaging time in a widely applied Scheffer Index (Scheffer 1971) is the primary reason for its limited success (Brischke and Rapp 2008; Larkin and Laks 2008). 
It would seem to be possible to apply the technique developed here in producing climate change prediction with regard to wood decay. For that purpose weather data were applied that are simulated by a numerical climate model (Räisänen et al. 2004), in addition to the ERA-40 weather data based on measurements. The simulated climate seems to be somewhat too moist, however, resulting in unrealistically fast wood decay. It is planned to correct the climate model data by the ERA-40 data in the future. This would allow making European wood decay maps with a higher resolution and predicting the change in the wood decay rate in Europe due to the global climate change. The authors believe that such projections would be much more reliable than those made by using the Scheffer Index (Liso et al. 2006). In any case, the model developed here, when applied to climate change studies, is a tool for risk assessment, and the uncertainties of the model need to be evaluated further.

Acknowledgement The authors gratefully acknowledge the financial support of WoodWisdom-Net and the wood industry partnership Building with Wood for funding the research work within the project WoodExter. The WoodExter research partners are thanked for their cooperation and collaboration in this project. ECMWF ERA-40 data used in this study were provided by ECMWF.

\section{References}

Boddy L (1983) The effect of temperature and water potential on growth rate of wood-rotting Basidiomycetes. Trans Br Mycol Soc 80: 141-149

Brischke C (2007) Investigation of decay influencing factors for service life prediction of exposed wooden components. Dissertation, University of Hamburg

Brischke C, Rapp AO (2008) Dose-response relationships between wood moisture content, wood temperature and fungal decay determined for 23 European field test sites. Wood Sci Technol 42: 507-518

Brischke C, Bayerbach R, Rapp, AO (2006) Decay-influencing factors: A basis for service life prediction of wood and wood based products. Wood Mater Sci Eng 1: 91-107 
Carll CG, Highley TL (1999) Decay of wood-based products above ground in buildings. J Testing Evaluation 27(2); 150-158

Foliente GC, Leicester RH, Wang C, Mackenzie C, Cole I. (2002) Durability design for wood construction. Forest Prod J 52(1):10-19

Heilmann-Clausen J, Boddy L (2005) Inhibition and stimulation effects in communities of wood decay: Fungi exudates from colonized wood influence growth by other species. Microbiol Ecol. 49: $399-406$

ISO 15686-1. Building and construction assets - Service life planning - Part 1: General principles.

Larkin GM, Laks PE (2008) To decay or not to decay: An accelerated field test on the validity of the Scheffer index. IRG Americas Regional Meeting, Playa Flamingo, Guanacaste, Costa Rica, 30 November - 2 December 2008

Leicester RH, Wang C-H, Ngyen MN, Thornton JD, Johnson G, Gardner D, Foliente GC, MacKenzie C (2003) An engineering model for the decay in timber in ground contact. Document No IRGWP 0320260. International Research Group on Wood Protection, Stockholm

Liso KR, Hygen HO, Kvande T, Thue JV (2006) Decay potential in wood structures using climate data. Building Res Inform 34(6):546-551

Lu JP, Leicester RH (1997) Effect of cyclic humidity exposure on moisture diffusion in wood. Wood Fiber Sci 29(1): 68-74

Råberg U, Edlund ML, Terziev N, Land CJ (2005) Testing and evaluation of natural durability of wood in above ground conditions in Europe - an overview. J Wood Sci 51:429-440.

Räisänen J, Hansson U, Ullerstig A, Döscher R, Graham LP, Jones C, Meier M, Samuelsson P, Willén U (2004) European climate in the late 21st century: regional simulations with two driving global models and two forcing scenarios. Climate Dyn 22:13-31

Scheffer TC (1971) A climate index for estimating potential for decay in wood structures above ground. Forest Prod J 21(10):25-31

Sedlbauer K (2001) Prediction of mould fungus formation on the surface of/and inside building components. Dissertation, University of Stuttgart

Uppala SM, Kallberg PW, Simmons AJ, Andrae U, Da Costa Bechtold V, Fiorion M, GIBSON JK, Haseler J, Hernandez, A, Kelly GA, Li X, Onogi K, Saarinen S, Sokka N, Allan RP, Andersson E, 
Arpe K, Balmaseda MA,Beljaars ACM, van de Berg L, Bidlot J, Bormann N, Caires S, Chevallier F, Dethof A, Dragosavac M, Fisher M, Fuentes M, Hagemann S, Holm E, Hoskins BJ, Isaksen L, Janssen PAEM, Jenne R, McNally AP, Mahfouf J-F, Morchette J-J, Rayner NA, Saunders RW, Simon P, Sterl A, Trenberth KE, Untch A, Vasiljevic D, Viterbo P, Woollen J (2005)

The ERA-40 re-analysis, Q. J. Roy. Meteorol. Soc., 131, 2961-3012

Viitanen H (1996) Factors affecting the development of mould and brown rot decay in wooden material and wooden structures. Effect of humidity, temperature and exposure time. Dissertation University of Uppsala

Viitanen H (1997a) Modelling the time factor in the development of mould fungi in wood - the effect of critical humidity and temperature conditions. Holzforschung 51(1):6-14

Viitanen H (1997b) Critical time of different humidity and temperature conditions for the development of brown rot decay in pine and spruce. Holzforschung 51(2):99-106

Viitanen H, Ritschkoff, A-C (1991a) Mould growth in pine and spruce sapwood in relation to air humidity and temperature. The Swedish University of Agricultural Scienses, Department of Forest Products, Report no 221, Uppsala

Viitanen H, Ritschkoff, A-C (1991b) Brown rot decay in wooden constructions. Effect of temperature, humidity and moisture. Swedish University of Agricultural Scienses, Department of Forest Products, Report no 222, Uppsala

Viitanen H, Ritschkoff, A-C, Ojanen T, Salonvaara M (2003) Moisture conditions and bio deterioration risk of building materials and structures. Proceedings of the $2^{\text {nd }}$ International Symposium ILCDES 2003. Integrated Lifetime Engineering of Buildings and Civil Infrastructures, Kuopio, 1-3 December 2003, 151-156

WUFI (Wärme und Feuchte instationär - Transient Heat and Moisture) 4.1 Pro software, The Fraunhofer Institute for Building Physics IBP

Wang CH, Leicester RH, Ngyen, MN (2008). Timber Service life design. Manual No 4. Decay above ground. CSIRO, Australia

Wilcox, WW (1978) Review of Literature on the Effects of Early Stages of Decay on Wood Strength. Wood Fiber 9(4):352-357 
Abb. 1

Dauer bis zum Beginn der Holzfäule bei unbehandeltem Kiefernsplintholz in Abhängigkeit der relativen Umgebungsluftfeuchte (RH) und Temperatur (Viitanen 1997a)

Abb. 2

Dauer bis zum Beginn der Holzfäule (weniger als 3\% Masseverlust) bei unbehandeltem Kiefernsplintholz in Abhängigkeit der relativen Umgebungsluftfeuchte (RH) und Temperatur (Viitanen 1997a)

Abb. 3

Fäuleentwicklung durch Coniophora puteana in einem Versuch nach EN 113:1997 bei hoher Umgebungsluftfeuchte (rel. Lf. 100\%) und unterschiedlichen Temperaturen. Die Fäuleentwicklung wird durch den vom Pilz verursachten Massenverlust bei unbehandeltem Kiefernsplintholz beschrieben. Die Kurven stellen die Mittelwerte der Laborversuchsdaten dar. (Viitanen 1996)

Abb. 4

Fäulewachstum beschrieben durch den Massenverlust von kleinen unbehandelten Kiefernsplintholzproben bei einer konstanten Temperatur von $15^{\circ} \mathrm{C}$ und unterschiedlicher Umgebungsluftfeuchte

Abb. 5

Berechnete Zeitdauer bis zum Fäulebeginn (Beginn Massenverlust) in Abhängigkeit unterschiedlich konstanter Temperaturen (x-Achse) und relativen Umgebungsluftfeuchten (verschiedene Kurven)

Abb. 6

Gemessene Jahresklimadaten in Helsinki, die für die Fäulemodellierung verwendet wurden

Abb. 7

Modellierter Aktivierungsparameter und Fäule im Verlauf von vier Jahren basierend auf der wiederholten Verwendung der Wetterdaten aus Abb. 6 
Abb. 8

Modellierte Massenverluste (in \%) von vor Regen geschütztem Kiefernsplintholz in Europa in einem Zeitraum von zehn Jahren

Abb. 9

Modellierte Massenverluste (in \%) von frei bewittertem Kiefernsplintholz in Europa in einem Zeitraum von zehn Jahren

Abb. 10

Modellierte Massenverluste (in \%) von Kiefernholz auf unterschiedlich ausgerichteten vertikalen Oberflächen, die Schlagregen ausgesetzt waren, in einem Zeitraum von zehn Jahren

Abb. 11

Querschnitt einer gut isolierten (320mm) Außenwand mit Hinterlüftungsschicht $(30 \mathrm{~mm})$

Abb. 12

Fäuleentwicklung einer 20mm dicken Holzaußenverkleidung aus unbehandeltem Kiefernsplintholz über einen Zeitraum von drei Jahren an drei Standorten in Europa, modelliert unter Verwendung der örtlichen Wetterdaten

Abb. 13

Einfluss des Schlagregenkoeffizienten R auf die Fäuleentwicklung einer 20mm starken Holzaußenverkleidung aus unbehandeltem Kiefernsplintholz. Die Wetterdaten der drei Jahre stammen aus Helsinki. 